\title{
Prevalence and clinical characteristics of otitis externa among patients attending Otorhinolaryngology Department at Muhimbili National Hospital, Tanzania
}

\section{Zephania Saitabau Abraham $^{1}$, Onesmo Tarimo ${ }^{2}$, Aveline Aloyce Kahinga ${ }^{3}$, Daudi Ntunaguzi ${ }^{3}$, Kassim Babu Mapondella ${ }^{3}$, Enica Richard Massawe ${ }^{3}$}

\begin{abstract}
${ }^{1}$ Department of Surgery, University of Dodoma, College of Health Sciences, Tanzania Department of Otorhinolaryngology, ${ }^{2}$ Mwananyamala Regional Referral Hospital, ${ }^{3}$ Muhimbili University of Health and Allied Sciences, Tanzania
\end{abstract}

Received: 13 February 2019

Revised: 17 May 2019

Accepted: 21 May 2019

\section{*Correspondence: \\ Dr. Zephania Saitabau Abraham, \\ E-mail: zsaitabau@yahoo.com}

Copyright: (C) the author(s), publisher and licensee Medip Academy. This is an open-access article distributed under the terms of the Creative Commons Attribution Non-Commercial License, which permits unrestricted non-commercial use, distribution, and reproduction in any medium, provided the original work is properly cited.

\begin{abstract}
Background: Otitis externa is among the otological diseases with significant impact on the quality of life of sufferers. Little is known in Sub Saharan countries despite being the focus of such disease. The study aimed to determine the prevalence and clinical characteristics of otitis externa at Muhimbili National Hospital, Tanzania's largest tertiary hospital.

Methods: This was a hospital based descriptive cross sectional study where 1200 participants were recruited from June 2016 to January 2017. Data was analyzed using SPSS program version 20.

Results: A total of 1200 patients were recruited in this study and majority 601(50.1\%) were females. Majority $672(56 \%)$ were in age group 0-10 years. Among 1200 patients, $138(11.5 \%)$ were diagnosed to have otitis externa and male predominance $(55.1 \%)$ was found. Majority $120(87 \%)$ had diffuse otitis externa and with $0-10$ years $(25.83 \%)$ being the commonly affected age group by variant. The commonest risk factor was self-ear cleansing $87(53.7 \%)$ and only $2.9 \%$ were found to have complications of otitis externa.

Conclusions: Otitis externa was found to be prevalent and with male predominance. Self-ear cleansing was the commonest risk factor. Complications of otitis externa were found to be rare. Public awareness on otitis externa should be advocated in our country.
\end{abstract}

Keywords: Prevalence, Clinical characteristics, Otitis externa, Muhimbili, Tanzania

\section{INTRODUCTION}

Otitis externa (OE) is an inflammation of the outer part of the ear which includes auricle, the external auditory canal (EAC), or both. It is a common disease that can be found in all age groups with no gender predilection. ${ }^{1}$ In otitis externa, bacterial species of Pseudomonas aeruginosa and Staphylococcus aureus are the two most isolates in acute bacterial infection, but can also be caused by other bacteria, fungal infection or viruses. ${ }^{2-5}$
There are several reported predisposing factors to otitis externa such as; wet ear, high humidity, increased temperature, absence of ear wax, allergic conditions or local trauma (e.g., use of hearing aids or cotton swabs). ${ }^{6}$ Swimmers are particularly prone to OE development because repeated exposure to water results in removal of cerumen and drying of the EAC. Retained water in the EAC may cause maceration of the skin and enhance proliferation to bacterial or fungal infection. Otitis externa occurs more often in the summer months, when 
swimming is more common, and it is also common in tropical areas. ${ }^{7}$ It was observed that $\mathrm{OE}$ rarely causes prolonged problems or serious complications when prompt diagnosis and appropriate therapy was administered. For untreated patients with OE or who are diabetic or immunocompromised may develop necrotizing (malignant) otitis externa which is a potentially life-threatening infection. ${ }^{8}$ Despite the little existing information about otitis externa, no study has been done in our county to characterize otitis externa despite being commonly encountered during routine ORL clinics. The aim of the study was thus to address the existing gap.

\section{METHODS}

A hospital based descriptive cross-sectional study was conducted between June 2016 and January 2017 and included all patients attending ORL Department at MNH. Convenient sampling method was utilized to recruit 1200 study participants after obtaining a written informed consent. Ethical approval to conduct the study was obtained from Research and Publication Ethical committees of Muhimbili University of Health and Allied Sciences (MUHAS) and the Muhimbili National Hospital $(\mathrm{MNH})$. Pretested structured questionnaires were used to collect data. After obtaining the relevant written informed consent from the study participants, complete ear, nose and throat examination was performed by the principal investigator and classification of otitis externa was made based on presenting clinical features such as circumscript (localized), diffuse and necrotizing (malignant) otitis externa. Data was analyzed using SPSS version 20 and p values below 0.005 were considered to be statistically significant. All patients who were found to have otitis externa were treated accordingly after their recruitment into the study.

\section{RESULTS}

\section{Age and sex distribution of study participants}

A total of 1200 study participants were recruited at $\mathrm{MNH}$ between June 2016 and January 2017. The proportion of males $(49.97 \%)$ was almost equal to that of females $(50.1 \%)$ in the ratio of $1: 1$. The study included patients aged 2-85 years with a mean of $18.29 \pm 1.89$. Majority 672 $(56 \%)$ of participants belonged to age group $0-10$ years (Table 1).

\section{Prevalence of otitis externa by age and sex}

Prevalence of OE in male was $76(12.9 \%)$ and in female was $62(10.3 \%)$. Age group with highest prevalence was $>60$ years 16(24.6\%). The p-value for age (0.000) was statistically significant and for $\operatorname{sex}(\mathrm{p}=0.198)$ was not statistically significant (Table 2).

Table 1: Age and sex distribution of study participants.

\begin{tabular}{|llll|}
\hline $\begin{array}{l}\text { Age group } \\
\text { (years) }\end{array}$ & $\begin{array}{l}\text { Sex } \\
\text { Male }\end{array}$ & Female & Total \\
\hline $\mathbf{N - 1 0}$ & $334(\mathbf{\%})$ & $\mathbf{N}(\mathbf{\%})$ & $\mathbf{N}(\mathbf{\%})$ \\
\hline $\mathbf{1 1 - 1 0}$ & $60(5.0)$ & $338(28.2)$ & $672(56.0)$ \\
\hline $\mathbf{2 1 - 3 0}$ & $57(4.6)$ & $65(5.4)$ & $125(10.4)$ \\
\hline $\mathbf{3 1 - 4 0}$ & $44(3.7)$ & $78(6.5)$ & $135(11.3)$ \\
\hline $\mathbf{4 1 - 5 0}$ & $35(2.9)$ & $40(3.3)$ & $64(7.0)$ \\
\hline $\mathbf{5 1 - 6 0}$ & $27(2.3)$ & $32(2.7)$ & $67(5.6)$ \\
\hline$>\mathbf{6 0}$ & $42(3.5)$ & $25(2.1)$ & $65(5.4)$ \\
\hline Total & $599(49.9)$ & $23(1.9)$ & $1200(100)$ \\
\hline
\end{tabular}

Table 2: Prevalence of otitis externa by age and sex.

\begin{tabular}{|c|c|c|c|c|}
\hline & & \multicolumn{2}{|c|}{ Otitis externa } & \multirow[b]{2}{*}{ Total } \\
\hline & & Yes & No & \\
\hline & & $\mathbf{N}(\%)$ & $\mathbf{N}(\%)$ & $\mathbf{N}(\%)$ \\
\hline \multirow{8}{*}{ Age group (years) } & $0-10$ & $40(6.0)$ & $632(94.0)$ & $672(56.0)$ \\
\hline & $11-20$ & $19(15.2)$ & $106(84.8)$ & $125(10.4)$ \\
\hline & $21-30$ & $20(14.8)$ & $115(85.2)$ & $135(11.3)$ \\
\hline & $31-40$ & $18(21.4)$ & $66(78.6)$ & $84(7.0)$ \\
\hline & $41-50$ & $15(22.4)$ & $52(77.6)$ & $67(5.6)$ \\
\hline & $51-60$ & $10(19.2)$ & $42(80.8)$ & $52(4.3)$ \\
\hline & $>60$ & $16(24.6)$ & $49(75.4)$ & $65(5.4)$ \\
\hline & Total & $138(11.5)$ & $1062(88.5)$ & $1200(100)$ \\
\hline \multirow{3}{*}{ Sex } & Male & $76(12.9)$ & $523(88.5)$ & 599 (49.9) \\
\hline & Female & $62(10.3)$ & $539(89.7)$ & $601(50.1)$ \\
\hline & Total & $138(11.5)$ & $1062(88.5)$ & $1200(100)$ \\
\hline
\end{tabular}


Table 3: Clinical types of otitis externa.

\begin{tabular}{|c|c|c|c|c|c|}
\hline & & \multicolumn{3}{|c|}{ Clinical type of otitis externa } & \multirow{2}{*}{ Total } \\
\hline & & Circumscript & Diffuse & Necrotizing & \\
\hline & & $\mathbf{N}(\%)$ & $\mathbf{N}(\%)$ & $\mathbf{N}(\%)$ & $\mathbf{N}(\%)$ \\
\hline \multirow{8}{*}{ Age group (years) } & $0-10$ & $9(22.5)$ & $31(77.5)$ & 0 & $40(29.0)$ \\
\hline & $11-20$ & $1(5.3)$ & $18(94.7)$ & 0 & $19(13.8)$ \\
\hline & $21-30$ & $4(20.0)$ & $16(80.0)$ & 0 & $20(14.5)$ \\
\hline & $31-40$ & $3(16.7)$ & $15(83.3)$ & 0 & $18(13.0)$ \\
\hline & $41-50$ & 0 & $15(100)$ & 0 & $15(10.9)$ \\
\hline & $51-60$ & 0 & $9(90.0)$ & $1(10.0)$ & $10(7.2)$ \\
\hline & $>60$ & 0 & $16(100)$ & 0 & $16(11.6)$ \\
\hline & Total & $17(12.3)$ & $120(87.0)$ & $1(0.7)$ & $138(100)$ \\
\hline \multirow[t]{3}{*}{ Sex } & Male & $10(13.2)$ & $65(85.5)$ & $1(13.3)$ & $76(55.1)$ \\
\hline & Female & $7(11.3)$ & $55(88.7)$ & 0 & $62(44.9)$ \\
\hline & Total & $17(12.3)$ & $120(87.0)$ & $1(0.7)$ & $138(100)$ \\
\hline
\end{tabular}

Table 4: Distribution of risk factors for $\mathrm{OE}$.

\begin{tabular}{|c|c|c|c|c|c|c|c|c|c|}
\hline & & \multicolumn{7}{|c|}{ Risk factors } & \multirow{3}{*}{ Total } \\
\hline & & \multirow[b]{2}{*}{ Wet ears } & \multirow{2}{*}{$\begin{array}{l}\text { Mechanical } \\
\text { trauma }\end{array}$} & \multicolumn{2}{|c|}{ Self-ear cleansing } & \multirow{2}{*}{$\begin{array}{l}\text { Chemical/ } \\
\text { Irritants }\end{array}$} & \multirow{2}{*}{$\begin{array}{l}\text { Low } \\
\text { immunity }\end{array}$} & \multirow[b]{2}{*}{ Others } & \\
\hline & & & & $\begin{array}{l}\text { Cotton } \\
\text { bud }\end{array}$ & Others & & & & \\
\hline & & $\mathbf{N}(\%)$ & $\mathbf{N}(\%)$ & $\mathbf{N}(\%)$ & $\mathbf{N}(\%)$ & $\mathbf{N}(\%)$ & $\mathbf{N}(\%)$ & $\mathbf{N}(\%)$ & $\mathbf{N}(\%)$ \\
\hline \multirow{9}{*}{$\begin{array}{l}\text { Age } \\
\text { group } \\
\text { (years) }\end{array}$} & $0-10$ & $9(10.1)$ & $23(25.8)$ & $47(52.8)$ & $4(4.5)$ & $2(2.2)$ & 0 & $4(4.5)$ & $89(16.7)$ \\
\hline & $11-20$ & $7(9.7)$ & $4(5.6)$ & $46(63.9)$ & $6(8.3)$ & $5(6.9)$ & 0 & $4(5.6)$ & $72(13.5)$ \\
\hline & $21-30$ & $24(22.2)$ & $2(1.9)$ & $50(46.3)$ & $5(4.6)$ & $20(18.5)$ & $3(2.8)$ & $4(3.7)$ & $108(20.2)$ \\
\hline & $31-40$ & $14(19.2)$ & $3(4.1)$ & $34(46.6)$ & $3(4.1)$ & $8(11)$ & $6(8.2)$ & $5(6.8)$ & $73(13.7)$ \\
\hline & $41-50$ & $8(11.9)$ & $2(3.0)$ & $36(53.7)$ & $5(7.5)$ & $11(16.4)$ & $3(4.5)$ & $2(3.0)$ & $67(12.5)$ \\
\hline & $51-60$ & $6(10.7)$ & $1(1.8)$ & $22(39.3)$ & $3(5.4)$ & $1(1.8)$ & $15(26.8)$ & $8(14.3)$ & $56(10.5)$ \\
\hline & $>60$ & $2(2.9)$ & $1(1.4)$ & $23(33.3)$ & $3(4.3)$ & $5(7.2)$ & $21(30.4)$ & $14(20.3)$ & $69(12.9)$ \\
\hline & \multirow{2}{*}{ Total } & \multirow{2}{*}{$70(13.1)$} & \multirow{2}{*}{$36(6.7)$} & $258(48.3)$ & $29(5.4)$ & \multirow{2}{*}{$52(9.7)$} & \multirow{2}{*}{$48(9)$} & \multirow{2}{*}{$41(7.7)$} & \multirow{2}{*}{$534(100)$} \\
\hline & & & & $287(53.7)$ & & & & & \\
\hline \multirow{4}{*}{ Sex } & Male & $29(41.4)$ & $23(63.9)$ & $114(44.2)$ & $8(27.6)$ & $1(1.9)$ & $22(45.8)$ & $30(73.2)$ & $227(42.5)$ \\
\hline & Female & $41(58.6)$ & $13(36.1)$ & $144(55.8)$ & $21(72.4)$ & $51(98.1)$ & $26(54.2)$ & $11(26.8)$ & $307(57.5)$ \\
\hline & \multirow{2}{*}{ Total } & \multirow{2}{*}{$70(13.1)$} & \multirow{2}{*}{$36(6.7)$} & $258(48.3)$ & $29(5.4)$ & \multirow{2}{*}{$52(9.7)$} & \multirow{2}{*}{$48(9)$} & \multirow{2}{*}{$41(7.7)$} & \multirow{2}{*}{$534(100)$} \\
\hline & & & & $287(53.7)$ & & & & & \\
\hline
\end{tabular}

\section{Clinical types of otitis externa}

Majority of the patients had diffused otitis externa 120 $(87.0 \%)$. The age group with high frequency were $0-10$ years. Male predominance was found in all the three types of otitis externa. ( $\mathrm{P}$ value for age and sex distribution $=0.076$, not statistically significant) (Table 3 ).

\section{Distribution of Risk factors for otitis externa}

The commonest risk factor encountered was self-ear cleansing $287(53.7 \%)$ and the most age group at risk was found to be 21-30 years 108 (20.25). Female preponderance $307(57.5 \%)$. The $\mathrm{p}$ value $(<0.005)$, statistically significant (Table 4).

\section{Complications of otitis externa}

Out of 138 patients with otitis externa, only 4 (2.9\%) were found to have such complications. Meatal stenosis was found in 3 adult patients (two males and one female) while one adult male had both mastoiditis and right sided facial nerve palsy.

\section{DISCUSSION}

To the best of our knowledge, this was the first study in our settings undertaken to elucidate the prevalence of otitis externa and its clinical characteristics thus unveiling the existing gap. The study recruited 1200 study participants and with almost no sex predilection reported for otitis externa. The prevalence of otitis externa in this study was found to be $11.5 \%$. Such prevalence appears to be different from what was found in Nigeria where it was found to be $4.4 \%$ and $3.4 \%$ in two studies. ${ }^{1,9}$ The observed differences may be attributed by variable geographical distribution of otitis externa and differences in terms of study duration.

No predominance was found in terms of prevalence of otitis externa in males and females similar to what was 
reported from Nigeria. ${ }^{1,9}$ In terms of age group affliction by $\mathrm{OE}$, patients aged $>65$ years were mostly affected in this study and such finding shows close resemblance to what was found in United Kingdom. ${ }^{10}$ A study from India among paediatric patients only found $\mathrm{OE}$ to predominate those aged up to 15 years (15\%), and similarly, 11-20 years aged patients were afflicted in about $15.2 \%$ of cases. ${ }^{11}$

The clinical type of OE which predominated in this study was diffuse otitis externa (87\%) while the least type was necrotizing otitis externa. Clinical characteristics of $\mathrm{OE}$ from this study depicts a similar pattern to what was documented by Kuylen et al. ${ }^{5}$

The commonest risk factor in this study was found to be self-ear cleansing $287(53.7 \%)$. Cotton bud users were $258(48.31 \%)$ with female predominance. Similar findings can be depicted from Nigeria where self-ear cleaning using cotton buds was the commonest risk factor. ${ }^{12}$ The low prevalence of OE found in Sokoto study could be to the fact that the subjects interviewed were those who attended family medicine clinic so they are less likely to have risks related to ears and hence a low prevalence compared to the subjects in this study. High percentage of habitual use of cotton buds for ear cleaning were also reported elsewhere. ${ }^{13,14}$

Otitis externa was found to be regularly associated with swimming and diving worldwide. ${ }^{15-18}$ Similar findings can also be depicted from this study.

Complications of OE were found in $4(2.9 \%)$ of patients and similar findings can be depicted from Nigeria where the study from Kaduna found no any complication of otitis externa. $^{11}$

\section{CONCLUSION}

Otitis externa was found to be prevalent and with male predominance in our setting. Similarly, self-ear cleansing was the commonest risk factor for Otitis externa. Public awareness on the risk factors for otitis externa should be advocated in our country.

\section{Funding: No funding sources}

Conflict of interest: None declared

Ethical approval: The study was approved by the Institutional Ethics Committee

\section{REFERENCES}

1. Ibiam FA, Godwin O. Acute otitis externa as seen at The University of Nigeria Teaching Hospital, Enugu. Otolaryngol Online J. 2013;3(2):1-6.

2. Mösges R, Baues CM, Schröder T, Sahin K. Acute bacterial otitis externa: efficacy and safety of topical treatment with an antibiotic ear drop formulation in comparison to glycerol treatment. Curr Med Res Opin. 2011;27(4):871-8.

3. Schaefer P, Baugh RF. Acute otitis externa: an update. Am Fam Physician. 2012;86(11):1055-61.

4. Enoz M, Sevinc I, Lapeña JF. Bacterial and fungal organisms in otitis externa patients without fungal infection risk factors in Erzurum, Turkey. Braz J Otorhinolaryngol. 2009;75(5):721-5.

5. Manni JJ, Kuylen K. Clinical and bacteriological studies in otitis externa in Dar es Salaam, Tanzania. Clin Otolaryngol Allied Sci. 1984;9(6):351-4.

6. Roland NJ, McRae RDR, McCombe AW (eds). Key topics in otolaryngology. 2nd Edition. Oxford, England: BIOS Scientific Publishers; 2001: 210 213.

7. Gray RF, Sharma A, Vowler SL. Relative humidity of the external auditory canal in normal and abnormal ears, and its pathogenic effect. Clin Otolaryngol. 2005;30(2):105-11.

8. Hollis S, Evans K. Management of malignant (necrotising) otitis externa. J Laryngol Otol. 2011;125(12):1212-7.

9. Uju IM, Nosa OE. Otologic diseases in a tertiary hospital in the Niger Delta region of Nigeria. J. Med. Med. Sci. 2013;4(3):96-100.

10. Rowlands S, Devalia H, Smith C, Hubbard R, Dean A. Otitis externa in UK general practice: a survey using the UK General Practice Research Database. Br J Gen Pract. 2001;51(468):533-8.

11. Basak B, Gayen GC, Ray R. Pattern of aural morbidity among children in a rural tertiary care hospital. IOSR J Pharm. 2013;3(7):58.

12. Amutta SB, Yunusa MA, Iseh KR, Obembe A, Egili E, Aliyu D, et al. Sociodemographic characteristics and prevalence of self ear cleaning in Sokoto metropolis. Int J Otorhinolaryngol Head Neck Surg. 2013;2(6):276.

13. Lee LM, Govindaraju R, Hon SK. Cotton bud and ear cleaning: a loose tip cotton bud? Med J Malaysia. 2005;60(1):85-8.

14. Dosemane D, Ganapathi K, Kanthila J. Knowledge, attitude and practice of ear care in coastal Karnataka. J Clin Diagn Res. 2015;9(12):MC01-4.

15. Wade TJ, Sams EA, Beach MJ, Collier SA, Dufour AP. The incidence and health burden of earaches attributable to recreational swimming in natural waters: a prospective cohort study. Environmental Health. 2013;12(1):67.

16. Neher A, Nagl M, Scholtz AW. Otitis externa. HNO. 2008;56(10):1067-80.

17. Springer GL, Shapiro ED. Fresh water swimming as a risk factor for otitis externa: a case-control study. Arch Environ Health. 1985;40(4):202-6.

18. Wang MC, Liu CY, Shiao AS, Wang T. Ear problems in swimmers. $\mathrm{J}$ Chin Med Assoc. 2005;68(8):347-52.

Cite this article as: Abraham ZS, Tarimo O, Kahinga AA, Ntunaguzi D, Mapondella KB, Massawe ER. Prevalence and clinical characteristics of otitis externa among patients attending Otorhinolaryngology Department at Muhimbili National Hospital, Tanzania. Int J Otorhinolaryngol Head Neck Surg 2019;5:826-9. 